U.S. Department of the Interior

U.S. Geological Survey
Water-Quality Assessment of the

Trinity River Basin, Texas

Pesticides in

By L.F. Land

\title{
Urban and Agricultural Streams, 1993-95
}

Nonpoint sources of pesticides are a national issue and are of major interest in the U.S. Geological Survey National Water-Quality Assessment (NAWQA) Program because of their potential toxicity to humans and aquatic life. Using the water-quality data collected by the Trinity River Basin NAWQA study-unit team, an analysis of pesticides in urban and agricultural streams was made by aggregating and grouping data from several networks. The samples were collected during March 1993 through September 1995. About 70 samples were collected from urban streams and 70 from agricultural streams. The urban dataset consists of sampling sites in the Dallas-Fort Worth metropolitan area where more than 3.5 million people lived in 1990. Land use in the sampled urban watersheds is primarily residential, but there are commercial areas, such as shopping centers and office complexes along major highways and streets. The agricultural dataset consists of sampling sites in the watershed of Richland-Chambers Reservoir, an area in the westcentral part of the Trinity River Basin where fertile soils are extensively cultivated. The land use is mostly cropland and pasture with some rangeland. In the cultivated areas, the major crops are corn, cotton, and sorghum. In the rangeland areas. cattle are the dominant livestock. In the pasture areas, hay is grown along with grass for cattle feed. None of the crops are irrigated.

The material in this fact sheet is condensed from a report by Land and Brown (1996) where the study is presented in greater detail.
Ten insecticides were detected in the urban streams and 10 in the agricultural streams. Although the number of compounds detected was the same, the frequency of detections was much greater in the urban streams, with carbaryl. chlorpyrifos, and diazinon occurring in more than half the urban samples.

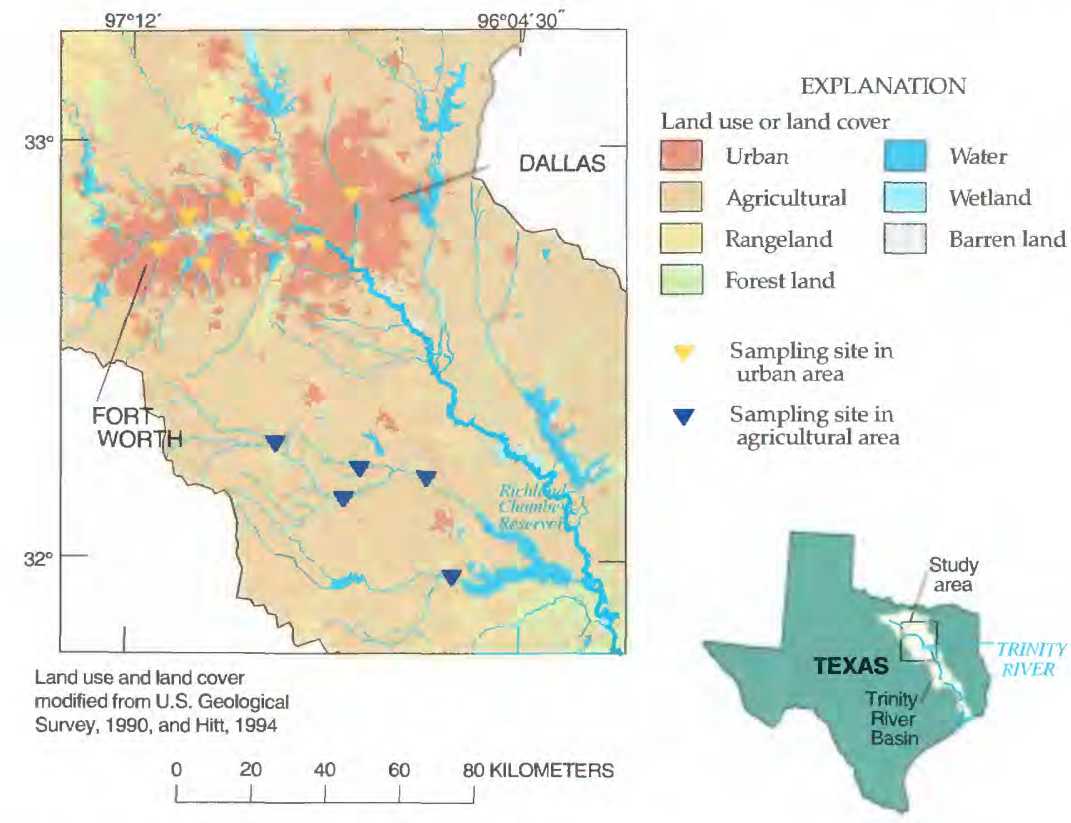
Diazinon was detected in all the samples from urban streams and in about 60 percent of the samples from agricultural streams. Other than diazinon, all insecticides in the agricultural streams occurred in less than 10 percent of the samples.

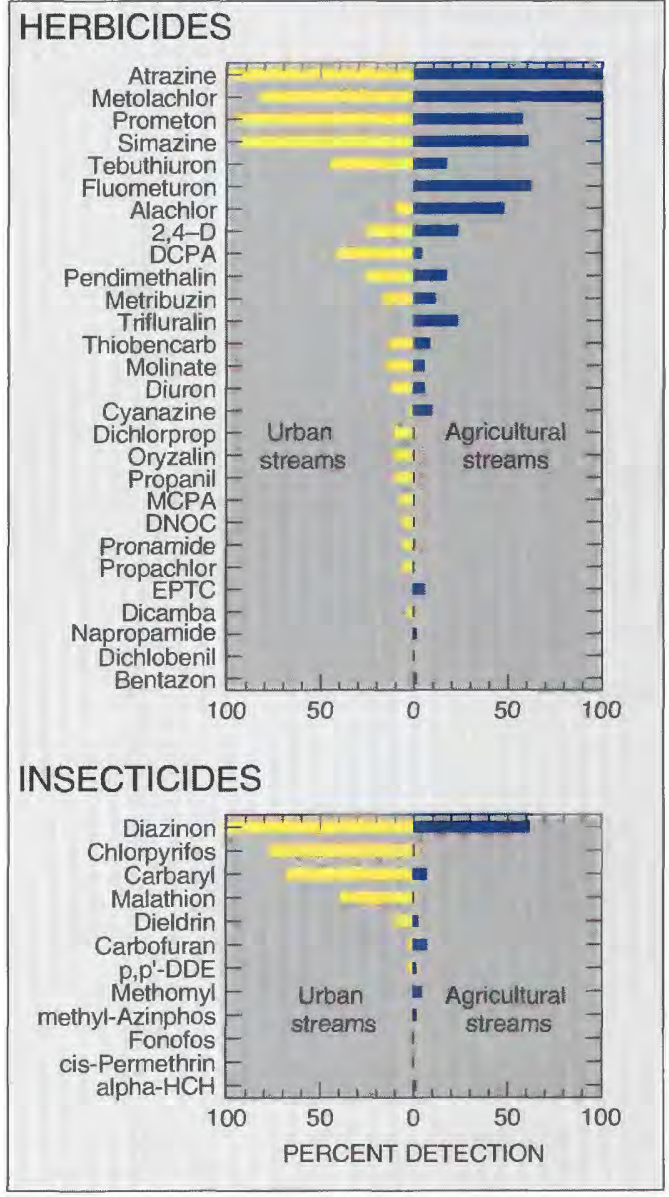

FREQUENCY OF DETECTION OF PESTICIDES

\section{What Were the Concentrations of Commonly Detected Pesticides?}

Boxplots of the five most frequently detected herbicides show that concentrations of atrazine and metolachlor generally were greater in the agricultural streams, while prometon and simazine generally were greater in the urban streams. Tebuthiuron concentrations generally were greater in the urban streams, but the maximum concentration was in an agricultural stream.

Three herbicides-atrazine, 2,4-D, and metolachlor - had maximum concentrations equal to or greater than 1.0 microgram per liter $(\mu \mathrm{g} / \mathrm{L})$ in both the urban and agricultural streams. In the agricultural area, two other herbicides, alachlor and fluometuron, had maximum concentrations greater than $1.0 \mu \mathrm{g} / \mathrm{L}$. Atrazine not only was the most frequently detected herbicide but also had the greatest median concentrations for both urban and agricultural streams. and in about 60 percent of the agricultural samples. 
Boxplots of the three most frequently detected insecticides show that the concentrations of each were greater in the urban streams than in the agricultural streams. Carbaryl and diazinon had maximum concentrations greater than $1.0 \mu \mathrm{g} / \mathrm{L}$ in urban streams.

The U.S. Environmental Protection Agency has established a maximum contaminant level (MCL) and a health advisory (HA) level for many pesticides (Nowell and Resek, 1994). Atrazine was the only herbicide with concentrations greater than the applicable water-quality standards. The MCL and HA for atrazine are $3 \mu \mathrm{g} / \mathrm{L}$. In the agricultural streams, approximately 20 percent of the samples exceeded this level. Diazinon was the only insecticide with concentrations greater than the applicable waterquality standards. The HA for diazinon is $0.6 \mu \mathrm{g} / \mathrm{L}$. (No MCL for diazinon has been set.) In the urban streams, approximately 15 percent of the diazinon samples exceeded this level.

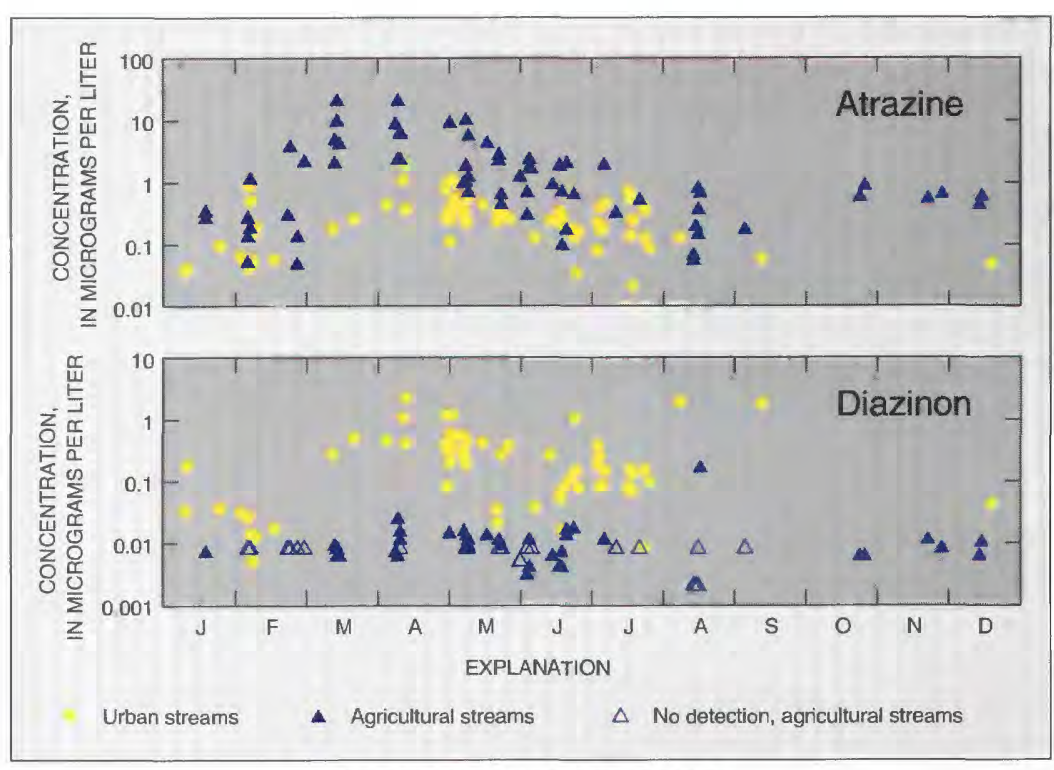

SEASONALITY OF PESTICIDES

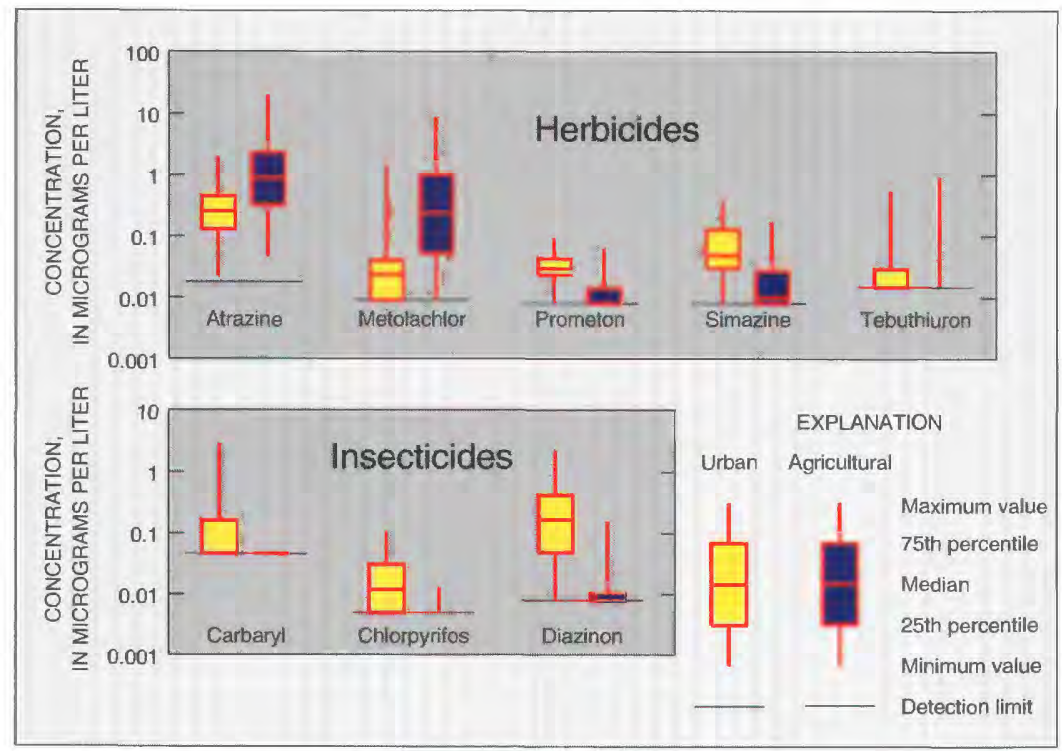

CONCENTRATIONS OF THE MOST COMMONLY DETECTED PESTICIDES

\section{When Were the Concentrations Greatest?}

Seasonal concentrations of the pesticides are illustrated by graphing the concentrations for the most commonly detected herbicide (atrazine) and the most commonly detected insecticide (diazinon) versus sampling date without regard to year.

The atrazine graph shows a great amount of scatter in concentration in both urban and agricultural streams. During April, the median concentration of atrazine was $0.8 \mu \mathrm{g} / \mathrm{L}$ in the urban streams and $6.0 \mu \mathrm{g} / \mathrm{L}$ in the agricultural streams. During September to January, when concentrations tended to be low, atrazine concentrations were about one-tenth of the concentrations in April in both types of streams.

The diazinon graph shows a great amount of scatter in concentration in the urban streams but not in the agricultural streams. In the urban streams, concentrations were greatest in April and were relatively high through August. During April, the median concentration was $0.21 \mu \mathrm{g} / \mathrm{L}$. During September to January, when concentrations tended to be low, diazinon concentrations were about one-half of the concentrations during April. Most of the diazinon concentrations in the agricultural streams were at or near the method detection limit; thus, no seasonality is evident.

\section{References}

Hitt, K.J., 1994, Refining 1970's land-use data with 1990 population data to indicate new residential development: U.S. Geological Survey Water-Resources Investigations Report 94-4250, 15 p.

Land, L.F., and Brown, M.F., 1996, Water-quality assessment of the Trinity River Basin, Texas - Pesticides in streams draining an urban and an agricultural area, 1993-95: U.S. Geological Survey Water-Resources Investigations Report 96-4114, 22 p.

Nowell, L.H., and Resek, E.A., 1994, Summary of national standards and guidelines for pesticides in water. bed sediment, and aquatic organisms and their applications to water-quality assessments: U.S. Geological Survey Open-File Report 94-455, 42 p.

U.S. Geological Survey, 1990, Land use and land cover digital data from 1:250,000- and 1:000,000-scale maps: U.S. Geological Survey Geodata Users Guide 4, 33 p.

Information on technical reports and hydrologic data related to the NAWQA Program can be obtained from: Project Chief

Trinity River Basin NAWQA Study

U.S. Geological Survey

8011 Cameron Road

Austin, Texas 78754-3898

E-mail: 1fland@usgs.gov

Any use of trade, product, or firm names is for descriptive purposes only and does not imply endorsement by the U.S. Government.

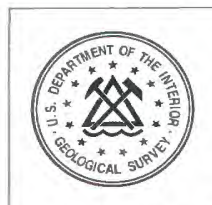

\section{The National Water-Quality} Assessment Program

The U.S. Geological Survey began the National Water-Quality Assessment (NAWQA) Program in 1991 to assess the status of and trends in the quality of the Nation's streams and aquifers. The program is designed to enhance understanding of natural and human factors that influence water quality, and consists of studies in 60 major river basins and aquifers of the United States. Together, the 60 studies compose about one-half of the land area of the United States and 60 to 70 percent of the water use and population served by public water supplies. The similar design of each study and use of consistent methods allow comparisons at regional and national scales. This information is being used to manage water resources at the national, State and local levels. 